\title{
ICELAND AFTER THE CRISIS - OPPORTUNITIES AND THREATS FOR DEVELOPMENT *
}

\author{
Ewa Szymanik ${ }^{1}$
}

\author{
UDC /UDK: 338(491.1) \\ JEL classification / JEL klasifikacija: O2 \\ DOI: https://doi.org/10.22598/pi-be/2017.11.2.133 \\ Review / Pregledni rad
}

Received / Primljeno: September 28, 2017 / 28. rujna 2017.

Accepted for publishing / Prihvaćeno za tisak: November 27, 2017 / 27. studenoga 2017.

\section{Summary}

The article presents the current situation in Iceland. It outlines its economic background and the causes of the past crisis. It also presents how it was overcome as well as what measures have been taken to avoid further breakdowns, as well as what conclusions resulted from it. Moreover, it indicates Island's main advantages and draws attention to the weaknesses and potential sources of the next crises, as well as the importance of having its own currency for the restructuring process.

Key words: Iceland, crisis, opportunities, threats, development.

\section{INTRODUCTION}

In recent years, Iceland has been the center of attention due to the crisis and the speed with which it overcame it. The pace and depth of the changes made Iceland a model country to others, such as Greece or Spain. Therefore, it is worth taking a closer look at its current situation and analyze the opportunities and threats for its further development.

The aim of the article is to present the current situation in Iceland and the sources of successfully overcoming the crisis, as well as to analyze the opportunities for further economic development, and draw attention to the possible risks and potential sources of

The paper was presented at the 2nd International Conference „Business \& Entrepreneurial Economics -BEE2017” which was held in Brijuni from 24 to 26 May 2017 (www.bee-conference.com)

1 Ewa Szymanik, Ph.D., Cracow University of Economics, Department of Microeconomics, Poland, E-mail:szymanie@uek.krakow.pl 
further breakdowns. There is no academic literature on this subject, only short articles and statistical data referred to in this text are available. In the light of the above, descriptive analysis was adopted as the research method.

\section{STYLIZED FACTS}

The economy of Iceland started to develop very quickly after a sharp downturn in 2008. According to The World Competitiveness Yearbook 2016 (IMD, 2016), Iceland was ranked 23rd in the world and 12th in Europe among the most competitive economies. Table 1 shows the current economic situation of Iceland.

Table 1: Economic situation of Iceland (selected years 2008-2015, 2016 - forecast)

\begin{tabular}{|l|c|c|c|c|c|c|c|}
\hline & $\mathbf{2 0 0 8}$ & $\mathbf{2 0 1 0}$ & $\mathbf{2 0 1 1}$ & $\mathbf{2 0 1 3}$ & $\mathbf{2 0 1 4}$ & $\mathbf{2 0 1 5}$ & $\mathbf{2 0 1 6}^{*}$ \\
\hline GDP (bln ISK) & 1551 & 1620 & 1702 & 1891 & 2006 & 2214 & 2309 \\
\hline GDP growth rate (\%) & 1.5 & -3.6 & 2 & 4.4 & 1.9 & 4.2 & 4.3 \\
\hline Inflation (\%) & 12.8 & 7.5 & 4.2 & 6 & 4.1 & 2 & 2.2 \\
\hline Unemployment rate (\%) & 3 & 7.6 & 7.1 & 5.4 & 4.9 & 3.4 & 3.4 \\
\hline $\begin{array}{l}\text { Average employment in tourism (\% } \\
\text { of employed) }\end{array}$ & 5.6 & 6.7 & 7.9 & 9.2 & 10 & 12.1 & 15 \\
\hline $\begin{array}{l}\text { Employment in sectors (\%): } \\
\text { Agriculture }\end{array}$ & 5 & 6 & 6 & 5 & 5 & - & - \\
\hline fishing & 2 & 3 & 3 & 2 & 2 & - & - \\
\hline industry & 22 & 18 & 18 & 19 & 18 & - & - \\
\hline services (total) & 73 & 76 & 76 & 77 & 77 & - & - \\
\hline Budget deficit/surplus (bln ISK) & -202 & -158 & -95 & -34.8 & -1.2 & -18.4 & - \\
\hline Budget deficit (\% GDP) & -13.1 & -9.8 & -5.6 & -1.9 & -0.1 & -0.8 & - \\
\hline External trade balance (bln ISK) & -6.7 & 120.2 & 97.1 & 40.2 & 4.3 & -30.6 & - \\
\hline Total export (bln ISK) & 2724.8 & 3581.1 & 3887.8 & 3969.3 & 3703.5 & 4173.9 & - \\
\hline Export (bln ISK): industrial products & 243.2 & 311 & 335.5 & 309.1 & 310 & 331.1 & - \\
\hline marine products & 171.4 & 220.5 & 251.6 & 272.5 & 244 & 264.6 & - \\
\hline Incomes by tourism & - & 163 & 197 & 277 & 305 & 370 & - \\
\hline
\end{tabular}

*data for 8 months

Source: own calculation on the basis of data from http://www.statice.is/, 22.10.2016

A positive growth rate, evident since 2011 (after the breakdown in years 2009-2010) is mainly a result of high government expenditure, although household expenditure has also grown slowly. The unemployment rate - always low - after a short period of growth during the deepest crisis, has declined again and is expected to fall to a sustainable level below $3 \%$. Iceland has again become a country with a net inflow of immigrants (Icelandic economic situation, 2015, pp. 3-14), who are mostly employed in the tourism sector.

Iceland is ranked 20th in the global ranking of economic freedom according to the Heritage Foundation, and 10th in Europe. It has got one of the best systems of protection of property rights, low corruption and high economic freedom. Tax reve- 
nue amounts to $35.5 \%$ of budget revenue while government expenditure has declined, constituting $43.9 \%$ of national expenditure. In 2015, public debt reached $80 \%$ of GDP (Heritage, 2016).

Therefore, it can be seen that after deep recession which reached bottom in 2011, the country is developing quickly. These positive changes are, among others, the result of a good use of loans obtained from IMF, the Nordic countries, Russia and Poland $^{2}$. The recovery program, a 6-year smooth path of cutting budget deficit (Koziel, 2016), was introduced in November 2008 and completed in August 2011. Thanks to the conducted activities Iceland managed to repay its loans before the due date - until autumn 2015 (Guðmundsson, 2016). In the same year Iceland was also the first country to reach and exceed the pre-crisis level of economic development.

\section{CHANGES IN ECONOMY}

The crisis caused major changes in the economy of Iceland. First, overheating of the economy stemmed from overinvestment in the energy sector developed mainly for the purposes of the aluminum industry (one should remember that Iceland has a poorly diversified structure of creating GDP - one of the main sources of income is fishing and industries associated with it, and this sector is very sensitive to economic fluctuations). It happened that the production of aluminum only was not essential, it was the construction that mattered, generating employment and constituting the main source of economic development. Second, previous reforms enabled the creation of financial bubbles and a threefold increase in prices on the real estate market (Sutowski, 2010, p.139), which was connected with an easy access to loans. The collapse of three large banks changed the situation dramatically - further rapid growth turned out to be impossible, debts of banks exceeded almost tenfold the value of GDP.

The costs of the crisis were high - they included a loss of approximately $20-25 \%$ of GDP. The IMF estimates were higher and amounted to $40 \%$. Net costs of fiscal support and restructuring of domestic banks amounted to 19.2\% of GDP (Davíðsdóttir's, 2015).

Problems which affected Icelanders came as a shock to them. They often did not have any savings, were accustomed to living with loans, so they could not cope at the moment of loss of their sources of income. Some of them emigrated and looked for work abroad, mainly in the Nordic countries. Apart from a rise in unemployment, the tax rate also increased (Budyta-Budzyńska, 2016, p.115) (although the tax revenue share in GDP fell from $17.6 \%$ in 2007 to $12.1 \%$ in 2009 , and in subsequent years was slightly above 13\%) (statice.is, 2016), while salaries remained unchanged. The level of consumption decreased, caused by the necessity to make savings.

In the face of these problems the authorities took radical action. Banks were allowed to collapse. It was decided (despite the pressure) not to repay debts to foreign creditors. People responsible for committing financial crimes were punished. The de-

Poland lent 214 million dollars to Iceland, from Polska udzieli... ,2008. 
valuation of the Icelandic króna (by 70\%) turned out to be a success that triggered inflation, which in 2009 amounted to $18 \%$ per year (Islandzki cud..., 2012). This led to a freeze in salary increase. The government changed its focus from the banking sector to traditional industries, such as fishing and tourism, and this change was helped by a decline in the value of the currency. Depositors were assured they would receive their bank deposits, national entities were granted reliefs in repaying existing loans, and the public expenditure was cut.

The devaluation of the currency helped to keep salaries at almost the same level, which saved household expenditure from a drastic decrease, even though the króna was worth less. This also led to an increase in export revenue (Matsangou, 2015, and Katsimi, Zoega, 2015). Thanks to this, the economy started to develop.

The authorities also drew conclusions about the causes and ways of avoiding similar breakdowns of the economy in the future. At the request of the Prime Minister of Iceland, a report was created indicating that the main source of the country's problems was the ease of excessive creation of money by commercial banks. Conclusions of the report show how to change this without disrupting the functioning of the entire banking system (a sovereign money system should serve this purpose, in which the entire possibility of money creation would belong exclusively to a central bank, and not like today - also to commercial banks) (Reforma monetarna, 2015).

A factor certainly contributing to development was the use of an unusual solution: rescuing its own economy by refusing to repay debts to foreign countries. The country was exposed to retaliatory actions by the United Kingdom (application of the Counter-terrorism Act and weakening of Island's military security by abolishing air patrols performed by the British forces, which was contested in front of NATO). It turned out, however, that such actions proved to be effective - the country developed very quickly.

Although in the end the government withdrew its application for accession to the EU (in March 2016), Iceland uses the conveniences of the European integration in a selective way - it belongs to the European Economic Area and the Schengen area, and this fact has ensured the free movement of people, capital and goods, which promotes development (it adopted 18\% of the regulations of the Union in order to make sure these freedoms were provided). Despite a severe currency crisis, the króna was not replaced by the Euro, and the country therefore continues to control its banking system and plans the above-mentioned financial reforms to avoid similar breakdowns in the future. In addition, the procedure of abolishing control of capital movement is ongoing (from 17 August 2016 it is again possible to acquire property abroad and financial instruments denominated in foreign currencies) (Iceland Economic..., 2016).

The collapse of the króna also contributed to an improvement of competitiveness of the economy. A great inflow of tourists took place after 2010, mainly from the United Kingdom, for whom holidays in the Land of Ice and Fire have become exotic - and cheaper. Iceland has become trendy and well-known because of the crisis. Iceland appeared in the global media and attracted public attention. In addition, the combination of the results of the Polish presidential plane crash in Smoleńsk and the eruption of Eyjaflallajökull, making global air traffic impossible for over 2 weeks, unintentionally assured free publicity to Iceland. 
Icelanders made a good use of the inflow of tourists. New accommodations, cafes, restaurants, unusual museums appeared (e.g. Museum of Rock'n'Roll). A network of bus connections was developed enabling the exploration of many attractive and difficult to reach places by using public transport operating during the summer, with long stops to sightsee the surroundings. In addition, a widely developed system of campsites and mountain shelters, the mountain rescue service and the tourist information service function smoothly. ${ }^{3}$

Figure 1: The number of employees in tourism sector - changes in relation to the previous year (monthly, in percentage) in years $2009-2016$

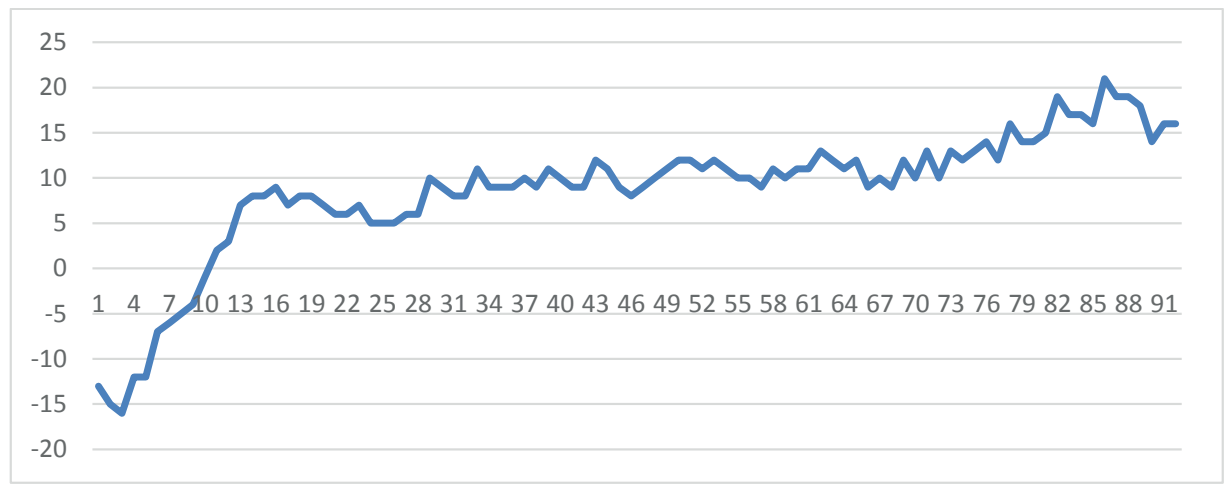

Source: on the basis of data from http://www.statice.is/, 22.10.2016

Although the economic collapse initially caused a turn towards the development of traditional sectors (fishing, tourism, aluminum production), there was, however, a dynamic shift towards the use and sale of renewable energy and the development of information technology (Shipman, 2016). There are plans to eliminate fossil fuels and replace them with hydrogen as the main fuel within 30-40 years. Yet, this does not prevent conducting oil exploration in the maritime zone of Iceland.

There are also threats. The Euler Hermes report from 2015 (Euler Hermes, 2015) indicates that a still disadvantageous structure of the economy, high public debt and external debt (up to 550\% of GDP) and a poorly protected banking sector are the weaknesses of the country. The exchange rate and risk of inflation are monitored but the threat of the collapse has not disappeared, despite the low energy prices and the appreciation of the króna. A slight increase in the nominal salary supported a growth of inflation expectations. In addition, sudden and large capital flows may lead to shortterm disequilibrium and exchange rate volatility, putting pressure on the balance of payments. This can be fostered by the liquidation of tax on withdrawn funds (amounting to 39\%) in June 2015 (introduced in 2009) (Amadeo, 2016), the aim of which was to prevent rapid outflow of foreign capital.

Own research 
Other threats result from a large share of traditional sectors still present in the economy. Fishing generates about $11 \%$ of GDP. Fish are, however, a source of income subject to many limitations, not allowing any control of supply or value. Tourism, the importance of which has increased greatly in recent years [in 2014 its total share in GDP, including its impact on other sectors of the economy, amounted to $23.3 \%$ and is expected to grow (Travel \& Tourism..., 2015, p3)], is also not free from disadvantages. One of them is the lack of ability to provide cheap meals for mass tourism (which is dominant). Therefore, the costs of food will grow which, combined with high prices for accommodation, will neutralize the positive effect of the devaluation of the króna, and naturally limit the inflow of visitors. It addition, it will make Iceland an exclusive tourist destination, where high prices play a minor role. The country is heavily dependent on oil, with fishing as its largest consumer. Moreover, the vast majority of products is imported. While oil prices were low, which was reflected on transport costs, the economy developed rapidly, which accelerated the process of overcoming the crisis. It is difficult to predict what the situation will look like in the future.

It is worth remembering that both the implemented reforms and the speed with which they were carried out, as well as their high efficiency, were also the result of specific characteristics of the discussed economy. Iceland is a small country, its residents are disciplined and have a high civil awareness. Because of this, and because of favorable external circumstances, as well as the subordination to recovery rules recommended by the IMF, the country managed to overcome the collapse quickly.

\section{CONCLUSIONS}

It is possible to draw some conclusions on the basis of the analysis of the available data. First of all, one of the important factors which contributed to the improvement of the situation of Iceland is a significant development of tourism. There was a very unusual contributing factor that had a positive impact on the tourist industry - the movies which were produced on the island (e.g. "Game of Thrones"). This means that another sector which might become a driving force of the economy is the sector of artistic creation (in 2012, more than 7 thousand companies were registered in this sector) (Islandzki cud..., 2012). It is worth noticing that the previously mentioned Heritage Foundation Report highlights significant facilitations for development of small enterprises within the existing regulation, with an emphasis on the use of environmentally friendly technologies and renewable sources of energy. This is also supported by a high transparency of the legal and economic system and a lack of corruption.

Iceland took advantage of its unusual competitive advantages: the activity of volcanoes (the eruption of Eyjafjallajökull aroused interest and attracted tourists), geothermal energy (to heat homes and greenhouses), and hydropower stations (aluminum production, server rooms). Global interest in this small country has increased, consequently influencing the inflow of financial resources from tourism and industry. Since there is a tradition of education in the humanities in the country, as well as a common knowledge of English, the country was not surprised by the wave of globalization and has been able to take advantage of the sudden increase in interest. 
It is estimated that in 2016 income from tourism will constitute 10\% of GDP (Tourism to bring..., 2016). It is worth noticing that even though the majority of tourists comes during the summer, the country is not empty in the winter - observing the aurora constitutes a major attraction (hotels in Reykjavik are fully booked especially in February) (Khan, 2016).

However, the disadvantages of the applied solutions have become evident. The private sector still has problems with getting funds for the development of companies, although the abolition of restrictions should change this. The low value of the króna does not mean that the country is low-priced - ISK 1000 is the basic unit of account, which makes costs of accommodation very high for an average visitor from abroad. Despite this, in the first half of 2016, tourist expenditure amounted to ISK 26 billion (USD 212 million) (Iceland rises...2016), which might be connected with a significant increase in accommodation prices - by 38\% since 2013 (Iceland hotel..., 2016).

The inflow of tourists is intense - it is estimated that in 2016 it will be more than 1700000 people. This is over five times more than the entire population of the country. On the one hand, this will lead to an increase in revenue, but on the other hand, it also means threats. The first threat is the development of accommodation - there are concerns that taking loans for new apartments that would be rented to tourists for short stays (e.g. by Airbnb website), will in a short time lead to a growth of another speculative bubble, this time generated by the real estate market (Landsbanki's forecast estimates that property prices will rise further by $25 \%$ in 2017) (Hayman, 2016). The increase in prices of accommodation will not last forever. Another threat is the burden to the natural environment caused by such a high number of visitors. Despite stringent regulations regarding environmental protection and rules on behavior in protected sites, not everybody obeys them (Poles are leaders in this shameful area), which may in the short term destroy the main magnet for tourists - Island's beautiful nature. It is therefore possible that the authorities will soon implement various limitations that will restrict the freedom of movement of tourists, especially individual ones which are very numerous (if not the majority), for example by strictly limiting the number of cars to rent or the number of daily visits to national parks. Moreover, jobs in the tourism sector do not require higher education, with the consequence that salaries are also not very high. Therefore, more and more foreigners work in this sector. During the crisis, educated Icelanders decided to emigrate temporarily or started their own business (How did Iceland..., 2016). The latter might become an additional driving force for the economy provided that they start IT companies. However, there is no doubt that a wider diversification of the economic base is needed.

The quick exit from the crisis was influenced by the fact that Iceland has its own currency. This enabled the local government to use an additional tool: control of the exchange rate. It is therefore possible to draw an important conclusion for both countries wishing to enter the Eurozone, as well as for the ones comprising it: one should not hurry with monetary integration. Economies must be very similar to each other, have a similar force of external impact and work together for a long time, in different phases of the business cycle (testing development possibilities and reacting to problems on their 
own and their partner's side) to make sure that the introduction of the common currency would not cause breakdowns and difficulties, as was the case in Greece. It is possible that deepening of cooperation in regions might support such integration.

In conclusion, it is worth observing further what is happening in the North of Europe - small Iceland can still teach us a lot.

\section{REFERENCES:}

1. Amadeo K., (2016). Iceland: Financial Crisis, Bankruptcy and Economy, The Balance, retrieved 18 September 2016, https://www.thebalance.com/iceland-financial-crisis-bankruptcy-and-economy-3306347

2. Budyta - Budzyńska M., (2016). Islandzki kryzys finansowy a strategie adaptacyjne Polaków na Islandii, retrieved 22 October 2016, http://www.migracje.civitas.edu. $\mathrm{pl} /$ migracje/index.php/pl/islandzki-kryzys-finansowy-a-strategie-adaptacyjne-polakow-na-islandii

3. Davíðsdóttir's S. (2015). Icelog, Iceland's recovery: myths and reality (or sound basics, decent policies, luck and no miracle), retrieved 23 September 2016, http://uti. is/2015/09/icelands-recovery-sound-basics-decent-policies-luck-and-no-miracle/

4. Euler Hermes, (2015). Retrieved 25. September 2016, http://www.eulerhermes.com/ economic-research/country-reports/Pages/Iceland.aspx

5. Guðmundsson M., (2016). Iceland's recovery - facts, myths, and the lesson learned, Islands Seðlabanki, retrieved October 2016, http://www.sedlabanki.is/library/ Skraarsafn/Raedur--erindi-og-greinar/LOKA\%20MG\%20Speech\%20in\%20London\%20OMFIF\%20lecture\%20Jan\%202016x\%20M.pdf

6. Hayman A., (2016). Iceland's recovery: on thin ice?, Property Week.com, retrieved 20 October 2016, http://www.propertyweek.com/in-depth/analysis-features/icelands-recovery-on-thin-ice?/5082003.article

7. Heritage Foundation (2016), http://www.heritage.org/index/country/iceland

8. How did Iceland clean up its banks?, (2016), retrieved 20 September 2016, http:// www.bbc.com/news/business-35485876

9. http://www.statice.is/

10. Iceland Economic Outlook, (2016). Focus Economic, Economic Forecast from the World's Leading Economists, retrieved 8 September 2016, http://www.focus-economics.com/countries/iceland

11. Icelandic economic situation overview, (2015). Ministry of Finance and Economic Affairs, March 2015. Reykjavik

12. Iceland hotel room prices up 38\% since 2013, (2016). Iceland Monitor, retrieved 27 October 2016, http://icelandmonitor.mbl.is/news/nature_and_travel/2016/09/27/ iceland_hotel_room_prices_up_38_prosent_since_2013/ 
13. Iceland rises from the ashes of 2008 financial meltdown, (2016), retrieved 21 September 2016, https://www.rt.com/business/352467-iceland-economy-huge-growth

14. Islandzki cud gospodarczy. Nie ratowali banków i interesów wierzycieli, (2012), retrieved 25 September 2016

15. http://tvn24bis.pl/wiadomosci-gospodarcze,71/islandzki-cud-gospodarczy-nie-ratowali-bankow-i-interesow-wierzycieli,281499.html

16. Katsimi M., Zoega G., (2015). Iceland vs Greece: Why such different results from IMF programmes?, WEF, retrived 18 September 2016, http://voxeu.org/article/imf-programmes-greece-vs-iceland

17. Khan M., (2016). A Brexit paradise: How Iceland's “Project Fear” backfired, Telegraph, retrieved 22 October 2016, http://www.telegraph.co.uk/business/2016/03/09/ from-bust-to-boom-is-iceland-a-brexit-paradise/

18. Kozieł H., (2016). Islandzka gospodarka złapała wiatr w żagle i szybko podnosi się po kryzysie, Rzeczpospolita, 29 Juni 2016

19. Matsangou E., (2015). Failing banks, winning economy: the truth about Iceland's recovery, World Finance, retrieved 8 September 2016, http://www.worldfinance. com/infrastructure-investment/government-policy/failing-banks-winning-economy-the-truth-about-icelands-recovery

20. Polska udzieli Islandii pomocy finansowej w wysokości $200 \mathrm{mln}$ dolarów.(2008), Gazeta Wyborcza 7 November 2008

21. Reforma monetarna. Lepszy system monetarny dla Islandii. Raport sporządzony przez Frosti Sigurjónssona na zlecenie premiera Islandii, (2015). Warszawa: Fundacja Jesteśmy Zmianą

22. Shipman A., (2016). Diamond geysers: rule - breaking Iceland completes its miracle economic escape, The Conversation, retrieved 20 September 2016, https://theconversation.com/diamond-geysers-rule-breaking-iceland-completes-its-miracle-economic-escape-59774

23. Sutowski M., (2010). Ostateczny krach systemu korporacji. In: Islandia. Przewodnik nieturystyczny, Warszawa: Wydawnictwo Krytyki Politycznej

24. The World Competitiveness Yearbook 2016, IMD, (2016), retrieved 23 October 2016, http://www.imd.org/uupload/imd.website/wcc/scoreboard.pdf,

25. Tourism to bring in $10 \%$ of Iceland's GDP in 2016. (2016). Iceland Monitor, retrieved 23 October 2016, http://icelandmonitor.mbl.is/news/nature_and_travel/2016/09/21/tourism_to_bring_in_10_prosent_of_iceland_s_gdp_in_/

26. Travel \&Tourism Economic Impact 2015. Iceland. (2015). London: World Travel \& Tourism Council 


\title{
ISLAND NAKON KRIZE - PRILIKE I PRIJETNJE RAZVOJU*
}

\author{
Ewa Szymanik ${ }^{4}$
}

\section{Sažetak}

Članak predstavlja trenutno stanje na Islandu. Daje naznake gospodarske pozadine i uzroka krize. Također opisuje kako je ona prevladana te koje su mjere poduzete kako bi se izbjegli daljnji potresi, kao i koje se pouke mogu izvući iz nje. Nadalje, ukazuje na glavne prednosti Islanda i skreće pozornost na slabosti i moguće izvore sljedeće krize, kao i na važnost postojanja vlastite valute za proces restrukturiranja.

Ključne riječi: Island, kriza, prilike, prijetnje, razvoj.

\section{JEL klasifikacija: $\mathrm{O2}$}

Rad je prezentiran na 2. Međunarodnoj konferenciji „Business \& Entrepreneurial Economics-BEE2017” koja je održana na Brijunima od 24. do 26. svibnja 2017. godine (www.bee-conference.com)

4 Dr. sc. Ewa Szymanik, Ekonomsko sveučilište u Krakovu, Poland, E-mail:szymanie@uek.krakow.pl 